\title{
TEPMIHOЗНАВСТВO
}

УДК $811.161 .2 ’ 373.46 ’ 373.45$

Л. Г. Боярова

\section{НІМЕЦЬКІ ЗАПОЗИЧЕННЯ В УКРАЇНСЬКІЙ ТЕРМІНОЛОГІЇ}

У статті проаналізовано німецькі запозичення в украӥнській термінології в кількох аспектах. До мовного аналізу залучено терміни німецького походження, кодифіковані в сучасних українських словниках різного типу. Розглянуто адаптування німецьких запозичень до фонетичної, морфологічної, словотвірної й тексико-семантичної систем української мови. Здійснено порівняльний аналіз семантики спеціальних мовних одиниць у тлумачних словниках української та німецької мов. Показано, що через німецьку мову в словниковому складі української мови з'явилося багато термінів з інших мов, серед яких переважають слова-латинізми й слова-греиизми. Підкреслено вплив німецької мови на становлення української й формування ї̈ як мови європейської.

Ключові слова: міжмовні контакти, українська термінологія, чужомовний термін, німецьке запозичення, адаптування запозичень.

Boiarova L. German Borrowings in Ukrainian Terminology. The appearance of German borrowings in the language of Ukrainians was stimulated by historical events in the life of the Ukrainian people and by the development of science and technology, thus testifying the influence of extra-linguistic factors on the development of the language and its vocabulary. Today, a special focus is made on the terminology of German origin, which has become an integral part of the Ukrainian terminology fund and plays a key role in professional communication between Ukrainians. The goal of the research is to study the terminology of German origin used in all life and activity spheres of Ukrainians and codified in modern Ukrainian dictionaries of various types, and to analyze German borrowing more thoroughly in some aspects, in particular, to pay a special attention to the lexical-semantic adaptation of these borrowings to the Ukrainian literary language. Considering the adaptation of German borrowings to phonetic, morphologic, word-formation and lexical semantic systems, Ukrainian as a target language is proved to be borrowing foreign words and adapting them to its system. The comparative analysis of special purpose language units given in the dictionaries of the Ukrainian and German languages was carried out. The examples of German borrowings and semantic changes during the adaptation by the target language are given. Thematic groups of the terms of German-language origin, functioning in the Ukrainian language, were indicated. The research 
conducted reveal that Ukrainian as a receiving language borrows foreign words and adapts them to its system on different levels, developing itself at the same time. This development is stimulated by linguistic and non-linguistic factors. The given examples clearly demonstrate that the terms from other languages, mostly Greek and Latin words, are shown to appear in the Ukrainian vocabulary through German. The influence of German on the Ukrainian language development and its formation as European one was emphasized.

Key words: interlingual contacts, Ukrainian terminology, foreign term, German borrowing, borrowing adaptation.

\section{Вступ}

Українсько-німецькі мовні контакти простежуємо протягом усієї історії української мови. Поява запозичень з німецької мови пов'язана з певними історичними подіями в житті українського народу та розвитком науки й техніки, що є впливом екстралінгвальних чинників на розвиток мови, ії словникового складу. «Можна вважати, що значною мірою німецькому впливові українська мова завдячує тим особливим місцем, яке вона сьогодні займає у європейсько-американському мовному і культурному ареалі, де вона поєднує риси східноєвропейські з відчутними характеристиками мови центральноєвропейської» (Акуленко, 1997: 18). Цей шар чужої лексики в мові українців став об’єктом дослідження як в українських, так і в західноєвропейських лінгвістів. Комплексний аналіз німецьких запозичень в українській мові здійснено в дисертаційних дослідженнях В. Скачкової (Скачкова, 1990) та О. Лисенко (Лисенко, 1999). В. Скачкова аналізує ці чужомовні слова на матеріалі художніх творів у семантичному та стилістичному аспектах, зокрема розглядає семантичне освоєння германізмів в українській літературній мові. У дисертації О. Лисенко об'єктом мовного аналізу обрано сучасну науково-технічну термінологію німецького походження, основним аспектом дослідження якої $є$ процес та результати освоєння чужих термінів в українській мові. Л. Кислюк розглянула в дисертаційній роботі словотвірний потенціал запозичень англійського та німецького походження в сучасній українській літературній мові й порівняла їх (Кислюк, 2000). Низку питань щодо функціонування германізмів в українській мові та їх адаптування до мови-приймача порушили в наукових розвідках Ю. БестерсДільер, С. Булик-Верхола, М. Гьофінггоф, М. Колесник, Т. Коробко, Т. Пиц, Е. Росберг, Ю. Теглівець, 3. Яким. Т. Пиц простежив вивчення 
німецьких запозичень в українській літературній мові та ії діалектах від кінця XVIII століття до сьогодні в Україні й німецькомовних країнах, зокрема в статті «До історії дослідження німецьких запозичених слів в українській мові» (Пиц, 2013). Грунтовний огляд наукових розвідок про германізми в мові українців уможливив такий висновок: «Отже, вивчення німецьких лексичних запозичених елементів в українській мові вже має свою історію здобутків і досягнень. Мовознавці виокремили їх із загального шару запозичень, розбили на тематичні групи, розрізнили два види: 1) ті, що етимологічно походять 3 німецької мови; 2) ті, що поширилися за допомогою німецької мови. Щоразу розширюється область їхнього аналізу: від пам'яток української мови попередніх віків до сучасної літературної мови (твори літератури, публіцистика, різні галузі науки і техніки), регіональних і соціальних діалектів. Також вивчено причини і шляхи поширення німецькомовної лексики, досліджується різнопланова адаптація у новому мовному середовищі» (Пиц, 2013: 96).

Ми проаналізували німецькі запозичення в мові українців у діахронії та синхронії в науковій розвідці «Deutsche Lehnwörter in der modernen ukrainischen Literatursprache», спираючись на запропоновану в національному мовознавстві періодизацію українсько-німецьких мовних контактів (Boyarova, 2018). На сьогодні особливої уваги потребує термінологія, запозичена з німецької мови, що стала складником українського термінофонду й відіграє велику роль у фаховій комунікації українців. Мета статті - дослідити термінолексику німецького походження, що вживається в усіх сферах життя й діяльності українців і кодифікована в сучасних українських словниках різного типу. Завдання - визначити роль німецької мови у формуванні українського термінофонду; розглянути в кількох аспектах адаптування німецьких термінів до української літературної мови; проаналізувати трансформації в плані змісту німецьких запозичень.

\section{Методи та методики дослідження}

Методи та методики дослідження зумовлені його метою й характером аналізованого матеріалу: описовий метод, що уможливлює систематизування мовного матеріалу, його інтерпретацію та узагальнення; зіставний метод, за допомогою якого встановлюються відмінні та спільні риси аналізованих термінів у мові-продуценті 
й мові-реципієнті на синхронному зрізі їхнього розвитку; компонентний аналіз на основі словникових дефініцій, який дає змогу виявити зміни в семантиці термінів німецького походження, адаптованих українською мовою; методика вибірки для виокремлення мовних одиниць, що є об’єктом дослідження.

\section{Результати та дискусіі}

У національному термінофонді $є$ значний шар термінолексики німецького походження, що весь час поповнюється й відбиває історію українсько-німецьких взаємин, а також історію мовних контактів німців. Німецька мова має багато запозичень з інших мов, які через неї з'явилися в українській термінології. Наприклад, через німецьку мову українці запозичили спеціальні слова з таких мов:

- латинської (латинська мова > німецька мова >): агент, адвока́m, а́нкер, лінза, клаві́р, ма́триия, меліс, ме́ргель, нейтраліте́т, пріорите́m, протубера́ниі, пульт, рарите́m, растр, рефера́m, рубін, сексте́m, септе́m, сигна́л, станіо́ль, ультима́тум, університе́т, факульте́m, фаши́на, фоліа́нт, циикуля́р, изта́ma, итати́в;

- французької (французька мова > німецька мова >): абоне́нт, адреса́нт, біржа, бригади́р, табе́т, маршру́m, раба́m, ранг, ранжи́р, рапіра, турні́р, бане́ра, фоле́йта, шабло́н;

- італійської (італійська мова > німецька мова >): жира́нт, кольра́бі, раке́та, траса́нm, траса́m, тріо́ль, шпага́m, штамn;

- грецької (грецька мова > німецька мова >): монаци́m, стро́біка, фагоцитоо́, изимоба́н, иийтра;

- арабської (арабська мова > німецька мова >): лю́бб́́, caлén;

- шведської (шведська мова > німецька мова >): кар (геолог.), ні́кель;

- нідерландської (нідерландська мова > німецька мова >): мáклер;

- англійської (англійська мова > німецька мова >): кокс;

- малайських мов (малайські мови > німецька мова >): какаду́;

- давньоєврейської (давньоєврейська мова > німецька мова >): бегемо́m.

Деякі слова, запозичені з німецької мови, з'явилися в мові-продуценті внаслідок мовних контактів кількох народів, наприклад:

- (грецька мова > латинська мова > німецька мова >): акáuія, аме́ба, муре́на, поліго́н (військ.), стра́ус; 
- (латинська мова > італійська мова > німецька мова >): карни́з, провіа́нт;

- (арабська мова > італійська мова > німецька мова >): марицпа́н;

- (французька мова > нідерландська мова > німецька мова >): павіа́н;

- (латинська мова > французька мова > німецька мова >): гри́фель;

- (іспанська мова > нідерландська мова > німецька мова >): nacám;

- (грецька мова > латинська мова > італійська мова > німецька мова >): ти́гель;

- (латинська мова > старофранцузька мова > нідерландська мова $>$ німецька мова >): кварти́ра;

- (давньоіндійська мова > тамільська мова > англійська мова > німецька мова >): кору́нд.

Через німецьку мову найбільше з'явилося в мові українців слівлатинізмів та слів-галліцизмів. «Вплив німецької мови на українську відбувався й посилювався протягом майже всього періоду їі становлення й розвитку як мови європейської. Німецька мова передавала сюди нові поняття та мовні форми їх втілення <...>. Вона сприяла підключенню української мови до мовно-культурних надбань як німецькомовної і всієї центральної Європи, так і латинської Європи античності і середньовіччя, а також французької культури рицарської і феодальної доби, Відродження, епохи абсолютизму і просвітництва, нарешті, новітньої європейської культури взагалі» (Акуленко, 1997: 17-18).

Терміни з німецької мови (автентичні й запозичені) прийшли в українську мову різними шляхами: безпосередньо з мови-продуцента (гарди́на, грабі́m, клаві́p, раба́m, риф, рол, тра́са, итати́в); через польську мову (кре́йда, кýля, папі́p, иу́кор, шлібува́тu, шпале́ра), через російську мову (аме́ба, кокс, комендату́ра, ла́икан, лабе́т, cmpáyc); через польську мову й через російську (аге́нт, бригади́р, бу́кса, кварти́ра); через західнослов'янські мови (баво́вна, ба́рва, муре́на). Походження німецьких слів і шляхи запозичування їх українською мовою відбивають історію мовних контактів давніх і сучасних народів.

Запозичені німецькі терміни одержали українське графічне оформлення, при цьому частина з них не зазнала суттєвих змін у вимові, наприклад: а́ншліф (Ánschliff), де́кель (Déckel), зе́нкер (Sénker), 
фа́льцер (Fálzer), фе́льдщер (Féldscher), шліи (Schlitz), шпат (Spat), шплінт (Splint), ипур (Spur), итаб (Stab), ште́кер (Stécker), ште́мпель (Stémpel), шурф (Schurf). Деякі німецькі запозичення вимовляються, як у мові-продуценті, але функціонують в українській мові з іншим наголосом, наприклад: абза́u (Ábsatz), uтандópm (Stándort). Значна кількість німецьких термінів має в українській мові відмінності у вимові або у вимові та наголосі порівняно з мовою-джерелом, наприклад: бере́йтер (Beréiter), ве́ркблей (Wérkblei), едельве́йс (Édelweiß), ме́ртель (Mö́rtel), нейзи́льбер (Néusilber), перламу́mp (Pérlmutter), ра́uniль (Ráspel), рейсфбédep (Réißfeder), роште́ŭн (Róhstein), шерл (Schörl), шпон (Span), uménceль (Stö́psel). Адаптування німецького терміна до морфологічної системи української мови - це насамперед втрата артикля, а також можлива поява флексії, що пришвидшує входження запозичення до відмінкових парадигм мови-реципієнта, наприклад: die Apparatúr - anapamýpa, die Wáffel - вáфля. У німецького слова, засвоєного українською мовою, часто змінюється рід, наприклад: die Fracht - фрахт (чол. р.), die Káchel - ка́хель (чол. р.), der Kólben - ко́лба (жін. p.), das Korn - корн (чол. p.), die Lósung - ло́зунг (чол. р.), der Schacht - щáxта (жін. р.), der Schirm - шúрма (жін. р.), das Vórsatz - фóрзаи (чол. рід), der Zápfen - u̧ánøaа (жін. р.), das Zink - изинк (чол. р.).

У науковій літературі наголошується, що важливим показником засвоєності чужого слова $€$ його входження до словотвірної системи мови-реципієнта. Мовний аналіз засвідчує, що переважна кількість німецьких термінів, пройшовши стадію ізольованого функціонування в мові українців, включилася в процеси термінотворення в ній. Одним із наслідків цього $є$ поява в українській мові гібридних форм за такими моделями: 1) приєднання до чужомовних слів українських афіксів чи афіксоїдів; 2) поєднання запозичених і національних слів чи коренів. За першою моделлю від термінів німецького походження утворилися іменники (баво́внищтво, крейдува́ння, фарбни́к, цегля́р), прикметники (е́ркерний, камерто́нний, куля́стий, перламу́тровий), дієслова (коксува́ти, масштабува́ти, итампува́ти, штемпелюва́тu). За другою моделлю в українській термінології з'явилася велика кількість таких гібридних утворень: баво́вна-сире́ць, коксога́сни́к, кран-уко́сина, ландщабтозна́вець, ланцюгозва́рювальний, фарборозпи́лювач, че́гла-сире́иь, чирищ-масля́нка, шрифтоносій. 
У науковій літературі висловлена думка, що гібридні слова свідчать про глибинний ступінь засвоєння запозичених елементів у мові, а також наголошено, що поєднання чужомовних слів із українськими словами є захисним механізмом мови-реципієнта: «Масове проникнення запозичень $<\ldots>$ почасти пом'якшується їхньою здатністю до гібридизації слів, коли запозичені основи поєднуються з питомими словами мови» (Клименко, 2008: 194). Автори монографії «Динамічні процеси в сучасному українському лексиконі» зауважили, що запозичення можуть утворювати в українській мові гнізда споріднених слів, у складі яких переважають гібридні форми. Наведені в цій праці приклади дають підставу для висновку, що велику кількість гібридів утворюють німецькі запозичення. Наприклад, гнізда з основами торф-о- та шлак-о-, що мають високий словотвірний потенціал: «Їхнє лексичне наповнення за даними аналізованого матеріалу становить відповідно 77 та 54 слова. Серед інших вони виділяються тим, що в їхньому складі переважають слова-гібриди (з основою торф-о- 45, шлак-о- 30)» (Клименко, 2008: 195). За нашими спостереженнями, у словотвірних гніздах від термінів німецького походження майже всі похідні мовні одиниці можуть бути гібридами. Наприклад, гібридні деривати утворюють словотвірну мікросистему таких германізмів: фа́рба (44), баво́вна (43), ча́хта (22), це́гла (21), чпиль (15), ичнк (13), шта́нга (11), штрих (10), штурм (9). Ми вважаємо слушною думку, що «< .. > гібридизація сприяє збагаченню мови (ії поняттєвого поля) і зміцнює іï життєстійкість, оскільки прокладає шляхи для формування нових стійких зв'язків між семантикою питомих слів, їхніх словотвірних та лексичних рядів і лексем змішаного гібридного типу, що називають нові поняття та реалії (Клименко, 2008: 200).

На особливу увагу заслуговує лексико-семантичний аспект засвоєння термінів німецького походження українською мовою. До аналізу залучаємо мовний матеріал, поданий у лексикографічній праці «Großes Wörterbuch der deutschen Sprache» в 10-ти томах (Wörterbuch), і порівнюємо з мовним матеріалом в академічному тлумачному «Словнику української мови» в 20-ти томах (на сьогодні опубліковано 10 томів цього видання) (Словник). Аналіз спеціальних мовних одиниць, кодифікованих в обох словниках, засвідчує, що в мові-продуценті й мові-реципієнті вони часто мають спільні плани змісту (здебільшого це моносемічні мовні одиниці). Наприклад 
(наведені словникові статті модифіковано: вилучено ілюстративний матеріал та ремарки, змінено лексикографічний спосіб кодифікування мовних одиниць):

Búchhalter - «Berufsbezeichnung: је- Бухга́лтер - «Фахівець із бухгалтерії (у 1 mand, der die Geschäfts-, Rechnungs- знач.); той, хто здійснює грошовий і матеріbücher eines Betriebes führt». альний облік».

Érker - «Geschlossener, mit Fenstern Éркер - «Напівкруглий, трикутний, чотириversehener Vorbau an Gebäuden». кутний або багатогранний засклений виступ у зовнішній стіні будинку».

Glétscher - «Großes Eisfeld, aus Firneis ле́тчер - «Скупчення на земній поверхні gebildete Eismasse, die sich in einem (в горах та приполярних районах) великих Strom langsam zu Tal bewegt». мас льоду, які рухаються під впливом власної ваги; льодовик».

Gneis - «Im Wesentlichen aus Quarz, Гнейс - «Метаморфічна гірська порода, Feldspat und Glimmer bestehendes Ge- до складу якої входять кварц, польові шпаstein». ти, слюда».

Karst - «Durch Wasser ausgelaugte, Карст - «Вигляд і властивість земної поan der Oberfläche meist kahle Gebirgs- верхні в тих ділянках, грунт яких складаlandschaft aus Kalkstein». ється з розчинних грубозернистих гірських порід (вапняків, гіпсів, кам’яної солі і т. ін.)».

Wáldhorn - «Blechblasinstrument mit Валтóрна - «Мідний музичний духовий інkreisförmig gewundenem Rohr, trich- струмент у вигляді спірально зігнутої труби terförmigem Mundstück, ausladender з широким розтрубом, який відзначається Stütze und drei Ventilen». м’якістю і повнотою звука».

У наведених мовних одиницях, як і в багатьох інших, співвідносні семеми в німецькій та українській мовах або максимально наближаються планом змісту (Búchhalter - бухга́лтер), або різняться мінімальними семантичними одиницями (семами) меншою (Gneis - гнейс, Karst - карст) чи більшою мірою (Érker - е́ркер, Glétscher гле́тчер, Wáldhorn - валто́рна). Певні відмінності в планах змісту запозичень німецького походження і їхніх прототипів у мові-джерелі можна пояснити, по-перше, наявністю в семемах німецьких термінів не лише експліцитних, але й імпліцитних сем, що можуть актуалізуватися під час засвоєння цих мовних одиниць українською мовою; по-друге, значущістю / незначущістю окремих сем для українських мовців. Такі відмінності на рівні сем не порушують спільності планів змісту мовних одиниць у мові-реципієнті й мові-продуценті, якщо в спеціальної мовної одиниці, що ввійшла до лексико-семантичної системи української літературної мови, на сигніфікативному рівні 
зберігається поняттєвий компонент значення вихідного слова, уживаного в німецькій мові.

Значна кількість термінів німецького походження має в мовіпродуценті два й більше значень, однак українська мова запозичує полісемантичну мовну одиницю здебільшого з одним зі значень, наприклад:

Dúbel - «1. a. Pflock, Zapfen, mit dessen Hilfe Дю́бель - «Чотиригранний Schrauben, Nägel, Haken u. a. in einer Wand стрижень, який гострим кінoder Decke fest verankert werden können. цем забивають у цегляну або b. Kurzform für: Spreizdübel. 2. (Bauwesen) Verbin- бетонну стіну для вгвинчуdungselement zum Zusammenhalten von Bauteilen». вання шурупів».

Grat - «1. Oberste Kante eines Bergrückens; [scharfe] Грат - «Зайвий метал, який Kammlinie. 2. a. (Bauwesen, Architektur) schräg ver- залишається на крайках вироlaufende Schnittlinie zweier Dachflächen. $\boldsymbol{b}$. (Bauwe- бів після обробки». sen, Architektur) Schnittlinie zweier Gewölbeflächen. 3. (Fachsprache) [beim Gießen, Stanzen usw. entstehende] scharfe, harte Kante; scharfkantiger Rand eines Werkstoffes. 4. ( Textilindustrie) aus der Gewebefläche heraustretende Bindungslinie mit schrägem Verlauf».

Sénker - «1. (Technik) einem Bohrer ähnliches Зе́нкер - «Металорізальний Werkzeug zum kegelförmigen Erweitern vor- інструмент для оброблення gebohrter Löcher. 2. (selten) Steckling; Ableger». стінок отворів».

Запозичання полісемантичного німецького слова з одним зі значень або з меншою кількістю значень $€$ звуженням семантичної структури чужомовної одиниці. Як різновид звуження плану змісту засвоєного німецького терміна розглядаємо «суміщення» двох його значень, кодифікованих у мові-продуценті, унаслідок чого він починає вживатися українцями з одним значенням:

Hántel - «1. (Turnen) Gerät zur Gymnastik oder Ганте́лі - «Гімнастичне знаzum Konditionstraining, bestehend aus zwei durch ряддя увиглядідвох чавунних einen Griff verbundenen Kugeln oder Schreiben. куль або набору металевих 2. (Gewichtheben) Eisenstange, an deren Enden дисків, з'єднаних короткою Gewichte in Form von Scheiben angebracht sind». ручкою».

Деякі німецькі терміни втрачають в українській мові значення, з яким вони вживаються в мові-продуценті, і набувають нової семантики, наприклад:

Sumpf - «Ständig feuchtes Gelände [mit stehendem Зумпф - «Яма на дні шахти Wasser] besonders in Flussniederungen und an для стікання води, нафти». Seeufern». 
Німецькі терміни можуть засвоюватися в українській мові зі значенням, що не завжди кодифікується в німецькій лексикографії. Наприклад, лексема Dunst може вживатися в мові німців зі значенням «Mahlprodukt in einer Korngröße zwischen Mehl und Grieß», але воно не зафіксовано в «Großes Wörterbuch der deutschen Sprache». Натомість зазначений «Словник української мови online» кодифікує німецьке запозичення дунст із такою семемою, а також ще з одним зі значень (2), поданих в аналізованому німецькому словнику:

Dunst - «1. a. neblige Luft, getrübte Erdatmo- Дунст - «1. Найдрібніший калібр sphäre. $\boldsymbol{b}$. von starkem Geruch [und Dampf] дробу (у 1 знач.). 2. Проміжний erfüllte Luft. 2. (Jägersprache) feinster Schrot продукт між крупою i боfür die Vogeljagd».

рошном при молотті».

Зіставлення кодифікованих лексем Dunst у мові-продуценті та дунст у мові-реципієнті дає підстави констатувати звуження семантичної структури засвоєного запозичення та одночасне ії розширення у сфері фіксування української мови.

Поданий мовний матеріал ілюструє процеси, що відбуваються в плані змісту німецьких термінів, коли вони засвоюються українською мовою. Як уже було відзначено, у цих мовних одиниць може бути як звуження, так і розширення їхньої семантики (іноді одночасно). Ці процеси виявляємо в семантичній структурі запозичень, і в окремих семемах. Звуження окремого значення зумовлено усуненням експліцитних сем, розширення - актуалізацією імпліцитних сем у семемі запозиченого терміна. Трансформація семантичної структури - це зменшення або збільшення кількості семем у засвоєному німецькому терміні. На адаптаційні процеси на лексико-семантичному рівні впливають позамовні чинники: теорія пізнання, ментальність українців, їхня мовна свідомість. У подальшому план змісту засвоєного німецького терміна може суттєво змінюватися, якщо термін переходить з однієї фахової термінології до іншої або починає вживатися поза певною терміносистемою, тобто в загальновживаній мові.

Німецькі терміни часто мають в українській мові маркери, за якими можна визначити їхнє походження. Фонетичним маркером здебільшого є сполучення двох звуків шт або шп на початку слова: штаб, шта́бель, штам, штамп, шта́нга, штати́в, штейн, штиб, штифт, шти́хель, шток, што́льня, штрек, штуф; шпина́т, шпи́ндель, шпіне́ль, шпіи, шпон, шпо́ра, шпре́нгель, шпринг, шпунт, 
шприи. Ще один маркер деяких германізмів - це відсутність між частинами запозиченого складного слова сполучного голосного звука: альпеншто́к, камерто́н, квершла́г, крейцко́пф, купферште́йн, ландша́бт, патронта́ш, цифербла́m, швертбо́m, члагба́ум, штангенци́ркуль, штокве́рк. Маркером німецьких слів $є$ також закінчення складного слова на -мейстер: гросме́йстер, капельме́йстер, кониертме́йстер, таниме́йстер, тонме́йстер, иеремонійме́йстер.

Спеціальні слова німецького походження, які українці сьогодні активно використовують, можна поділити на такі тематичні групи: ремесло та виробництво, техніка, торгівля, транспорт, військова справа, економіка, суспільно-політична сфера, управління, посади й титули, флора й фауна, медицина, культура, мистецтво, спорт, побут. Окремою групою слід виділити наукові терміни, що прийшли в українську мову з німецької, насамперед філософські та психологічні.

\section{Висновки}

Мовний аналіз засвідчує, що в сучасній національній термінології функціонує велика кількість запозичень з німецької мови, адаптованих до системи української мови на фонетичному, морфологічному, словотвірному й лексико-семантичному рівнях. 3 поглибленням процесу адаптування німецьких термінів до української мови на них усе більше впливають особливості мови-реципієнта, тобто лінгвальні чинники. Асимільовані чужомовні одиниці втрачають властивості, які вони мають у мові-джерелі, і їхнє подальше функціонування в українській мові визначають іiі мовні норми. Ступінь освоєння німецькомовних запозичень значною мірою залежить від часу їхньої появи в мові українців, а також від когнітивно-комунікативної значущості для носіїв української мови.

Поданий матеріал дає підстави для висновку, що національна мова українців відкрита до запозичень, зокрема німецьких, і має великий потенціал для освоєння чужомовних слів. Як мова-реципієнт вона зреалізовує свої системні можливості, змінюючись при цьому, що є розвитком ії̈ мовної системи, зумовленим і лінгвальними, і позалінгвальними чинниками. Світові інтеграційні процеси формують єдиний інформаційний простір, а отже, уніфікують науковий поняттєвий апарат, і тому можна спрогнозувати, що й надалі в українських терміносистемах з'являтимуться чужомовні слова, які проходитимуть складний шлях адаптування до мови-реципієнта. 


\section{ЛIТЕРАТУРА}

1. Акуленко В. В. Німецький вплив на розвиток української мови: проблеми методології. Мовознавство. 1997. № 1. С. 12-19. 2. Кислюк Л. П. Словотвірний потенціал запозичень у сучасній українській літературній мові (на матеріалі англійських та німецьких запозичень): автореф. дис. ... канд. філол. наук. Київ, 2000. 17 с. 3. Клименко Н. Ф., Карпіловська Є. А., Кислюк Л. П. Динамічні процеси в сучасному українському лексиконі. Київ: Вид. дім Дмитра Бураго, 2008. 336 с. 4. Лисенко О. А. Освоєння німецькомовних запозичень в українській науково-технічній термінології: автореф. дис. ... канд. філол. наук. Харків, 1999. 21 с. 5. Пиц Т. До історії дослідження німецьких запозичених слів в українській мові. Українська мова. 2013. № 2. С. 84-99. 6. Скачкова В. В. Немецкие лексические заимствования в современном украинском литературном языке: автореф. дис. ... канд. філол. наук. Харьков, 1990. 24 c. 7. Boyarova L. Deutsche Lehnwörter in der modernen ukrainischen Literatursprache. Galizien und die Galiziendeutschen (1914-1940): Interpretationen und Quellen im Kontext. Redakteur: Katrin Boeckh (Hrsg.). Herne: Freunde der Martin-Opitz-Bibliotek, 2018, 125138 .

\section{ДЖЕРЕЛА}

8. Словник української мови online. URL: http://services.ulif.org.ua/expl/Entry/ index?wordid=1\&page=0. 9. Das große Wörterbuch der deutschen Sprache. URL: https:// www.duden.de/Shop/Duden-Das-grosse-Worterbuch-der-deutschen-Sprache-0.

\section{REFERENCES}

1. Akulenko, V. V. (1997). Nimetskyi vplyv na rozvytok ukrainskoi movy: problemy metodolohii [German influence on the development of the Ukrainian language: problems of methodology]. Movoznavstvo - Linguistics, 1, 12-19 [in Ukrainian]. 2. Kysliuk, L. P. (2000). Slovotvirnyi potentsial zapozychen u suchasnii ukrainskii literaturnii movi (na materiali anhliiskykh ta nimetskykh zapozychen [Word building potential of modern Ukrainian literary language (a case study of English and German borrowings)]. Extended abstract of candidate's thesis. Kyiv: NAN Ukraine, IUM [in Ukrainian]. 3. Klymenko, N. F., Karpilovska, Ye. A. \& Kysliuk, L. P. (2008). Dynamichni protsesy v suchasnomu ukrainskomu leksykoni [Dynamic processes in the modern Ukrainian lexicon]. Kyiv: Vyd. dim D. Buraho [in Ukrainian]. 4. Lysenko, O. A. (1999). Osvoiennia nimetskomovnykh zapozychen $\mathrm{v}$ ukrainskii naukovo-tekhnichnii terminolohii [Adoption of German language borrowings in Ukrainian scientific and technical terminology]. Extended abstract of candidate's thesis. Kharkiv: KhDU [in Ukrainian]. 5. Pyts, T. (2013). Do istorii doslidzhennia nimetskykh zapozychenykh sliv v ukrainskii movi [To the research history of German loan words in Ukrainian language]. Ukrainska mova - Ukrainian language, 2, 84-99 [in Ukrainian]. 6. Skachkova, V. V. (1990). Nemeckie leksicheskie zaimstvovaniya v sovremennom ukrainskom literaturnom yazyke [German lexical borrowings in modern Ukrainian literary language]. Extended abstract of candidate's thesis. Kharkov: KhHU [in Russian]. 7. Boyarova, L. (2018). Deutsche Lehnwörter in der modernen ukrainischen Literatursprache [German loanwords in the modern Ukrainian literary language]. Galizien und die Galiziendeutschen (1914-1940): Interpretationen und Quellen im Kontext - Galicia and the Galician Germans (1914-1940): interpretations and sources in context. Redakteur: Katrin Boeckh (Hrsg.). Herne: Freunde der Martin-Opitz-Bibliotek, 125-138 [in German]. 


\section{DZHERELA - SOURCES}

8. Slovnyk ukrainskoi movy online [Dictionary of Ukrainian language online]. Retrieved from http://services.ulif.org.ua/expl/Entry/index?wordid=1\&page $=0$ [in Ukrainian]. 9. Das große Wörterbuch der deutschen Sprache [The large dictionary of the German language]. Retrieved from https://www.duden.de/Shop/Duden-Das-grosse-Worterbuchder-deutschen-Sprache-0 [in German].

Боярова Людмила Георгївна - кандидат філологічних наук, доцент, професор кафедри української мови, Харківський національний університет імені В. Н. Каразіна; площа Свободи, 4, м. Харків, 61022, Україна.

Tel.: +38-057-707-54-58

E-mail: lgbpage@meta.ua

https://orcid.org/0000-0002-9944-2380

Boyarova Liudmyla - Ph.D in Philology, Associate Professor, Professor, Ukrainian Language Department, V. N. Karazin Kharkiv National University; Freedom Sqr. 4, Kharkiv, 61000, Ukraine.

Надійшла до редакції 11 лютого 2020 року 